\title{
Analysis of Financial Ratio towards Earning Growth in Mining Companies
}

\author{
Purwanto $^{1, *}$, Chelsea Risa Bina ${ }^{2}$ \\ ${ }^{1}$ Faculty of Economic and Business, Padjajaran University, Indonesia \\ ${ }^{2}$ Faculty of Business, President University, Indonesia
}

Copyright $(\mathrm{C} 2016$ by authors, all rights reserved. Authors agree that this article remains permanently open access under the terms of the Creative Commons Attribution License 4.0 International License.

\begin{abstract}
This research aims to identify the influence of working capital to total asset, debt to equity ratio, total asset turnover, and net profit margin predicting the earning growth. Population of this research is the mining industry companies listing in Indonesia Stock Exchange. The writer gets 60 samples from 20 companies in period 2010 until 2012. The method that is used in collecting data is documentation method and done by taking financial data in IDX corner. The result of regression shows that variable of working capital to total asset and debt to equity ratio partially having negative but significant influence on the predicting earning growth. The variable of total asset turnover and net profit margin, partially having positive and significance influence. Simultaneously, four variables have significant influence on earning growth with the predictive capabilities of $37.2 \%$ and the remaining $62.8 \%$ is influenced by other factors that are not included in this regression model.
\end{abstract}

Keywords Working Capital to Total Asset, Debt to Equity Ratio, Total Asset Turnover, Net Profit Margin, Earning Growth

\section{Introduction}

In order to enter any market or profession, the most important motivation and reason for most people is earning, while different personal, social situation and income return can influence the direction of investment. Opportunities and threats always exit in stock markets. Distinguishing proper time for increasing earning and avoiding loss depends on skills and performance of investors. (Indonesia-Investments, 2013). Indonesia has a long history in the oil and gas industry and also in coal industry with a diversity of geological, which continue to offer sizeable mining potential. The biggest beneficiary of domestic and foreign direct investment in Indonesia came from the mining sector. Investments in Indonesia's mining sector rose 23.8 percent in the first six months of 2013 compared to the same period in
2012.

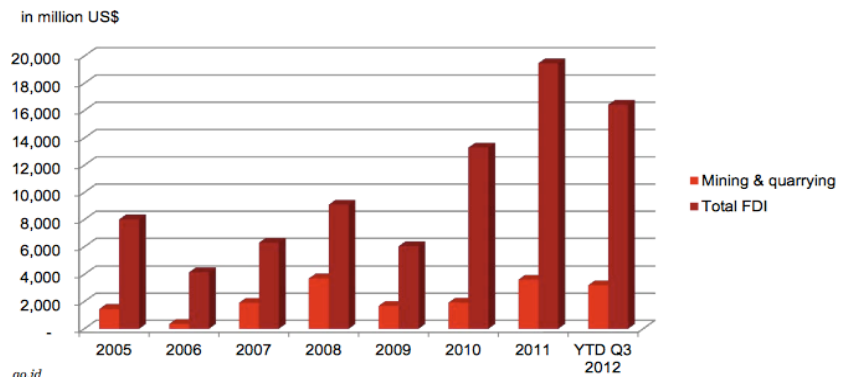

Figure 1. Trend of Foreign Direct Investment (FDI) in Indonesia

Based on the figure 1, in 2011 shows a significant increase both for mining investment and FDI in general, with 2012 likely to show a slight increase. The researcher can see mining industry in Indonesia is the great country for mining sector. In other some challenge in the industries in Indonesia, the mining industry companies will be continue their operations and production in Indonesia by make many new planning to take it in more investment area (Indonesia-Inve stments, 2013).

This research is intended to conduct further testing of empirical findings concerning financial ratios, especially regarding its usefulness in predicting the Earning Growth of mining industry that listed in Indonesia Stock Exchange based on their financial ratio. Therefore, present research is attempted to analyze WCTA, DER, TAT, and NPM in predict the earning growth.

\section{Literature Review and Hypotheses}

\subsection{Mining Industry}

According to Indonesian mining sector - market snapshot (2013), Indonesia as the fourth largest population and the largest economy in South East Asia, has the world's largest reserves of mineral. Indonesia is has a wide range of key mining. Indonesia is the second largest producer of nickel and tin and the fourth largest copper producer in the world. 
Besides that, Indonesia also has a significant quantity of coal, gold, bauxite, phosphates and iron sand produces; and has the potential for alluvial diamond production. Mining industry accounted for 10.8 percent of Indonesia GDP on 2009 with minerals and contributing 20 percent of the country's total export for related source.

This up and down of mining industry rates start in 2008 after a significant drop in profit as a result of the global economic crisis. Then mining companies in Indonesia experienced improved profitability over the following three years (2009-2011). However, return on shareholders' funds continued to decrease over the same period.(Indonesian mining sector - market snapshot, 2013). During 2010 - 2011, the profitability of mining companies in Indonesia, as a whole, was relatively flat. While coal companies recorded significant increases in both revenue and net income, the results of mineral companies told a totally different story with significant decreases in both revenue and net income during 2011. The main reason was a decrease in the production levels of mineral companies although this was offset to some degree by increases in mineral prices.

\subsection{Earning Growth}

In general, the researcher can say that earnings growth is a key indicator for measuring a company's success or not. According to Morse (2010) that said recent studies on the behavior of earnings growth over time raise doubt about the ability of past growth to explain differences in price earnings ratios. Either future growth is difficult to predict, or investors are basing their predictions on information other than past growth. A single company, this increase in growth is clearly possible if the business is easily scalable or if offsetting transactions (e.g., share buybacks) are undertaken and investment policy is unaffected. By similar reasoning, many observers would accordingly expect a strong and reliably negative relationship between payout ratios and future earnings growth for the market as a whole. Looking at the recent policy of low payouts, this view, if true, would offer grounds for optimism regarding future earnings growth (Arnott, 2003).

\subsection{Working Capital to Total Assets (WCTA)}

Working capital to total assets is the liquidity of the total assets and working capital position. Working capital is meant here is the net working capital, which is part of the current assets that can actually be used to finance the company's operations without disturbing liquidity. According to Mehmet (2009), working capital means the whole current assets owned by a firm. Return of total assets of a firm as a result of an activity is closely related to level and distribution of assets of the firm and efficiency in application of these assets. In lots of firms current assets called working capital make up of a remarkable part of community assets. Working capital to total assets ratio is the liquidity of the total assets and working capital position.
Working capital is meant here is the net working capital, which is part of the current assets can actually be used to finance the company's operations without disturbing liquidity. When WCTA become the higher ratio, there is the greater portion of the working capital of the company from total assets. With large working capital, the company's operations are expected to be smooth so that the income will increase and this resulted in profits earned also increased. The research result conducted by Takarini \& Erni (2003) shows that WCTA has positive and significance influence to earnings growth, but according to Hartini (2012), WCTA has positive but not significance to earnings growth.

\subsection{Debt to Equity Ratio (DER)}

Debt/equity ratio is equal to long-term debt divided by common shareholders' equity. Typically the data from the prior fiscal year is used in the calculation. Investing in a company with a higher debt/equity ratio may be riskier, especially in times of rising interest rates, due to the additional interest that has to be paid out for the debt. If a lot of debt is used to finance increased operations (high debt to equity), the company could potentially generate more earnings than it would have without this outside financing. If this were to increase earnings by a greater amount than the debt cost (interest), then the shareholders benefit as more earnings are being spread among the same amount of shareholders. However, the cost of this debt financing may outweigh the return that the company generates on the debt through investment and business activities and become too much for the company to handle. DER ratio illustrates the company's ability fulfill the obligations to equity. Sariguna (2011) mentions the ratio of debt to equity is an attempt to show, in other formats, the relative proportions of the lender the right to ownership and used as a measure of the role of debt. According to Kuswadi(2005), companies with high DER will have difficulty to obtain additional funds from outside. Liability is not something bad if it can provide benefits to its owner and used effectively and earned enough income to pay the interest charges on a periodic basis. With high DER companies bear the risk of loss is high but also the opportunity to earn increased profits. DER high impact on improving earnings changes, meant to give effect to the company's profit. The journal research result conducted by Hartini (2012) shows that DER has positive and significance influence to earnings growth.

\subsection{Total Asset Turnover (TAT)}

Total assets turnover is the ratio between sales to total assets ratio in a company, which describes the rotation speed of its total assets in a given period. Total assets turnover is a ratio that indicates the level of efficiency of the overall assets of the company in generating a certain sales volume (Mohammed, 2012). Total assets turnover is a ratio that describes the turnover of assets measured by the volume of sales. If the ratio get bigger is better, which means that the assets can be quickly turned and made a 
profit and showed more efficient use of the overall assets in generating sales. In other words, the same amount of assets that can increase sales volume if the assets turn over enhanced or enlarged. Total assets turnover is important for creditors and owners of the company, but will be more important for the management of the company, as this will indicate whether or not efficient use of all the assets in the company. TAT is used to measure the ability of the company using its assets in generating total net sales. The greater the TAT showed more efficient use of the entire assets of the company to support sales activities. This indicates that the better performance of the company, therefore the investors are interested to invest their money, so it can increase its profit. In explanation by Jan (2011): if the result of TAT is higher, the company has improved efficiency and produced more sales per asset. If the ratio is lower, the firm might be experiencing lower sales for a variety of internal or external reasons. Inventory might consist of outdated, less-desirable products. Creditors might be taking longer than usual to pay, keeping the firm's accounts receivable balance too high. The firm might also be under-utilizing its buildings and machinery, leading to a lower TAT ratio. The research result conducted by Hapsari (2007) shows that TAT has positive and significance influence to earnings growth.

\subsection{Net Profit Margin (NPM)}

When doing a simple profitability ratio analysis, net profit margin is the most often margin ratio used. The net profit margin shows how much of each sales dollar shows up as net income after all expenses are paid. For example, if the net profit margin is $5 \%$ that means that 5 cents of every dollar is profit. The net profit margin measures profitability after consideration of all expenses including taxes, interest, and depreciation. According to Setiawan (2012), net profit margin is the ratio of the used to demonstrate the company's ability to generate net profits after taxes. Meanwhile, according to Bastian (2006), net profit margin is the ratio between the net incomes by sales. Accounting information from financial reports can describe firm's condition. The financial reports are affected by two factors; firms' activities and accounting system adopted by the firm Krishna G. Palepu (2004). There are many researches in value of financial reports information (both annual and interim reports). Some researches study accounting information in predicting firms' future financial performance, such as earnings and growth while other researches measure the effect of accounting on earning growth. Profit margin is an accounting tool frequently used by accountants and financial analysts to determine the percentage of sales that is converted into net profit. It shows the ratio between net profit and total sales for a given time period. In a business, net profit margin is one of its most fundamental measures of profitability and overall success. While net profit margins can impact many parts of a business, they often affect inventory management in some way. According to Hutami(2012), this ratio interprets the company's efficiency levels, the extent of the company's ability to press the costs of its operations in a particular period. The greater this ratio is better because of the ability of the company to make a profit through the sale of fairly high as well as the ability of the company to reduce costs and charges reasonably well. Conversely, if this ratio down furthers the company's ability to earn income through the sale is considered quite low. The research result conducted by Hapsari(2007) shows that NPM has positive and significance influence to earnings growth. And the journal by Adisetiawan(2012), also said that NPM has positive and significance influence to earnings growth.

\subsection{Theoretical Framework}

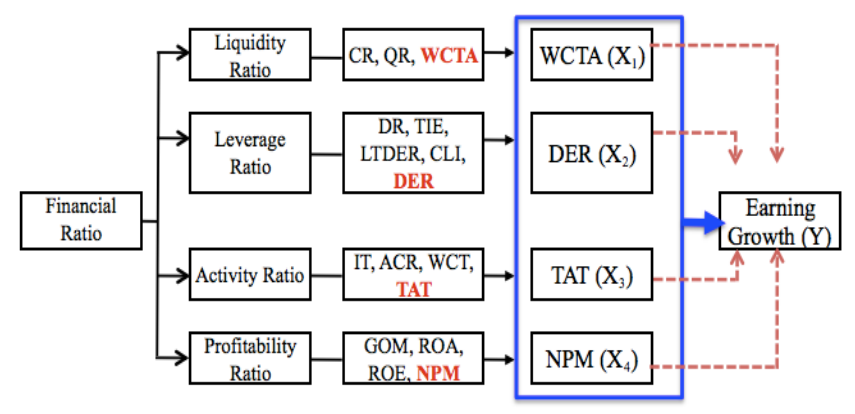

Figure 2. Theoretical Framework

The figure 2 shows that the blue line explain that independent variables (WCTA as X1, DER as X2, TAT as $\mathrm{X} 3$, and NPM as X4) simultaneously influence the dependent variable (Earning Growth as Y). And the red-dot line is explained the independent variables partially influence the dependent variable.

\subsection{Hypotheses}

"Hypotheses $(\mathrm{H})$ can be defined as a testable prediction about what you expect to happen in your study" (Ajith \& Shalini, 2001). Given the theoretical background as discussed above, this study attempts to hypothesize $(\mathrm{H})$ the following:

H1: There is a significant influence of working capital to total asset on predicting earnings growth.

$\mathrm{H} 2$ : There is a significant influence of debt to equity ratio on predicting earnings growth.

H3: There is a significant influence of total asset turn over on predicting earnings growth.

H4: There is a significant influence of net profit margin on predicting earnings growth.

H5: There is a significant influence of whole independent variables on predicting earnings growth simultaneously.

\section{Research Design}

\subsection{Research Method}

According to Anderson (2006), quantitative research options have been define by a large number of respondents 
are involved in the research. By definition, the research measurement must be objective, quantitative and also statistically valid. Simply put, it's about numbers and objective data. The researcher using formulas to define how large a sample size will be needed from a given population in order to achieve findings with an acceptable degree of accuracy calculate the sample size for a survey. Whereas Anderson (2006) also said, quantitative research refers to counts and measures of things, qualitative research refers to the meanings, concepts, definitions, characteristics, metaphors, symbols, and descriptions of things. Then, the step for qualitative research start from the step of collecting, analyzing, and interpreting data by observing what people or organization do and say. The researcher used the quantitative analysis as the research method. Specifically, the type of the research is descriptive method, which includes a lot of numerical calculation and description of the result obtained. Data used in this research is secondary data (data that has been publish or collected by another party) obtained from Indonesia Stock Exchange.

\subsection{Population and Sample}

Sampling is a process that used in statistical analysis in a predetermined number observation will be taken from large population. The methodology used to sample from a larger population will depend on the type of analysis that being performed. According to Sugiyono (2006), population is a region consisting of generalization object/subjects that have certain qualities and characteristics are determined by the researchers to learn and drawn the conclusions. And sample is part of the number and characteristics possessed by the population. The population in this research is all of the mining companies that listed in Indonesia Stock Exchange, and the sample are 20 companies of mining industry that listed in Indonesia Stock Exchange who has complete annual financial report during of period 2010-2012 that will be used to calculate every variables in this research with total sample is 60 . Here are the 20 mining companies that listed in Indonesia Stock Exchange that used for this research:
a. PT. ATPK Resources Tbk.
b. PT. Berau Coal Energy Tbk.
c. PT. BUMI Resources Tbk.
d. PT. Bayan Resources Tbk.
e. PT. Golden Energy Mines Tbk.
f. PT. Harum Energy Tbk.
g. PT. Indo TambangrayaMegahTbk.
h. PT. Resource Alam Indonesia Tbk.
i. PT. Myoh Technology Tbk.
j. PT. Bukit AsamTbk.
k. PT. Adaro Energy Tbk.
1. PT. Citra Kebun Raya AgriTbk.
m. PT. J Resources Asia PasificTbk.
n. PT. Timah (Persero) Tbk.
o. PT. CitatahTbk.
p. PT. RatuPrabuEneriTbk.
q. PT. Benakat Petroleum Energy Tbk.

r. PT. Medco Energi International Tbk.

s. PT. Radiant UtamaInterinscoTbk.

t. PT. Energy Mega PersadaTbk.

\subsection{Multiple Regression Analysis}

Statistical process for estimating the relationship between a variable to another variables is namely as regression analysis (Setiawan, 2010). In economics, the dependent variable may be some data of consumption expenditure and the independent variables may be the company's income, and other factors that would affect the company's consumption patterns. In the linear regression model, the dependent variable is assumed to be a linear function of one or more independent variables plus an error introduced to account for all other factors:

$$
Y=\beta_{0}+\beta_{1} X_{1}+\beta_{2} X_{2}+\beta_{3} X_{3}+\beta_{4} X_{4}+e
$$

$\mathrm{Y}$ is earning growth (EG), $\beta 0$ is constant, $\mathrm{X} 1$ is working capital to total asset, $\mathrm{X} 2$ is debt to equity ratio, $\mathrm{X} 3$ is total asset turnover, $\mathrm{X} 4$ is net profit margin, $\beta 1 \ldots . . \beta 4$ are regression coefficient and e is error.

\section{Result and Discussion}

\subsection{Descriptive Statistics}

Descriptive statistical analysis aims to describe all the variables involve within the research. The samples for this research is 20 mining industry that listed in Indonesia Stock Exchange with the observation period for 3 years, start from 2010 until 2012. So, the total observation of this research is 60 samples. The objects for this study are the effect of WCTA, DER, TAT, and NPM of predicting Earning Growth.

Table 1. Descriptive Statistic

\begin{tabular}{|c|c|c|c|c|c|}
\hline & $\mathrm{N}$ & Minimum & Maximum & Mean & Std. Deviation \\
\hline WCTA & 60 & -.7850 & .9890 & .018267 & .3734252 \\
\hline DER & 60 & -1.7560 & 17.7540 & 1.678317 & 2.5729607 \\
\hline TAT & 60 & .0000 & 2.2360 & .298667 & .3463352 \\
\hline NPM & 60 & -1.7600 & 1.8000 & .088883 & .3912037 \\
\hline EG & 60 & -4.2820 & 7.9240 & .200783 & 1.7888454 \\
\hline Valid N (list wise) & 60 & & & & \\
\hline
\end{tabular}

Table 1 will describe the minimum and maximum values, the mean or average, and also the standard deviation of data distribution. The standard deviation will explain how far the data value away from average of the data value. Evaluate descriptive statistics is needed to be able to ensure that the data are normally distributed. Based on table 1 can be seen that the lowest value of earnings growth as the dependent variable is $-428.2 \%$ and the highest profit growth is $792.4 \%$. The average value (mean) of the earnings growth is about $20.07 \%$ to the level of standard deviation $178.88 \%$. 
The first independent variable is WCTA. The lowest value of WCTA is $-78.50 \%$ and the highest value (maximum) is $98.90 \%$. The average value (mean) of WCTA is $1.82 \%$ to the level of standard deviation of $37.34 \%$. The second independent variable is DER. The lowest value of DER is $-175.60 \%$ and the highest value (maximum) is $177.54 \%$. The average value (mean) of DER is $167.31 \%$ to the level of standard deviation of $257.29 \%$. The third independent variable is TAT with the lowest value 0.00 and the highest value is $223.60 \%$. The average value of TAT is 0.298667 or $29.86 \%$ to the level of standard deviation of $34.63 \%$. The last independent variable is NPM. The lowest value of NPM is $-176 \%$ and the highest value is $180 \%$. The average value (mean) of NPM is $8.88 \%$ to the level of standard deviation of $39.12 \%$.

\subsection{Multiple Regression Analysis}

This study examined and tested several variables that can effect on predicting Earning Growth. Multiple regression analysis is used in this research because the researcher conducted studies more than one variable. Regression analysis used to determine the effect of independent variables on dependent variable.

Table 2.Regression Model Result

\begin{tabular}{|c|c|c|c|c|c|c|}
\hline \multirow{2}{*}{ Model } & \multicolumn{2}{|c|}{$\begin{array}{c}\text { Unstandardized } \\
\text { Coefficients }\end{array}$} & $\begin{array}{c}\text { Standardized } \\
\text { Coefficients }\end{array}$ & \multirow{2}{*}{$\mathrm{t}$} & \multirow{2}{*}{ Sig. } \\
\cline { 2 - 7 } & B & Std. Error & Beta & & \\
\hline \multirow{4}{*}{1} & (Constant) & .001 & .284 & & .004 & .997 \\
\cline { 2 - 7 } & WCTA & -1.417 & .573 & -.296 & -2.474 & .016 \\
\cline { 2 - 7 } & DER & -.264 & .083 & -.379 & -3.159 & .003 \\
\cline { 2 - 7 } & TAT & 1.550 & .553 & .300 & 2.803 & .007 \\
\hline & NPM & 2.305 & .485 & .504 & 4.757 & .000 \\
\hline
\end{tabular}

Based on the result in table 2, the regression equation is as follow:

$$
\mathrm{EG}=-0.296 \text { WCTA-0.379 DER + 0.300 TAT + 0.504 NPM }
$$

Researcher used the beta value from the standardized coefficient with the reason because of the indicator of all variables is same. According to Sunyoto (2009) on his book, the unstandardized coefficient is use when the indicator measurement of the variables is different. Example is the variables indicator measurement is using years, dollars, inches, miles, and pounds in one case, so it's better to use unstandardized coefficient, but vice versa if the indicator measurement is same (e.g., using percentage in all variable) in one case, it's better to use the standardized coefficient.

Negative value of intercept on regression equation is the result of negative data input, which is the loss experienced by companies. According to Rietvield(1994), negative value of interception does not mean the regression equation incorrect, as long as the BLUE (Best Linear Unbiased Estimator), which measured by the classical assumption test, fulfilled. Then, from the analysis above, it can be seen the explanation of result as follow: a) The first value result is came from WCTA with the beta coefficient is -0.296 . The negative coefficient indicates the negative effect to the Earning Growth, which means if there is an increase 1 percent of WCTA, the Earning Growth will be decreased by $-29.6 \%$.

b) The second value result is came from DER with the beta coefficient is -0.379 . Which means, if there is an increase 1 percent of DER, the Earning Growth will be decreased by $-37.9 \%$.

c) The third variable is TAT, with the beta coefficient is about 0.300 . The positive coefficient indicates the TAT has the positive effect to Earning Growth. If there is an increase 1 percent of TAT, the Earning Growth will be increased by $30 \%$.

d) The last variable is NPM, with the beta coefficient is about 0.504 . This is the biggest value of the variable that influences the Earning Growth in this research. The positive coefficient indicates the NPM has the positive effect to Earning Growth and if there is an increase 1 percent of NPM, the Earning Growth will be increased by $50.4 \%$.

\section{Interpretation of Result}

a. The Influence of Working Capital to Total Asset toward Earning Growth

The analysis result in table 2, the variable of WCTA has the result of t-test is -2.474 with the significance value of 0.016 and beta is -0.296 . The value of $t$ is absolute and the negative value is a sign that the value has opposite impact to dependent variable. The significance value less than or equal to 0.05 , it can be conclude to accept the alternative hypothesis and reject the null hypothesis. Researcher can conclude that $\mathrm{Ha}$ is accepted; with the condition of WCTA has a negative but significant influence on predicting earning growth.

The existing empirical data and research results obtained indicating that the proportion of the rise and fall WCTA variable which is the ratio between working capital (current assets less current liabilities) to total assets does affect profit growth.

b. The Influence of Debt to Equity Ratio toward Earning Growth

The variable DER indicates of t-test result is about -3.159, with the significance value is 0.03 and regression coefficient $(\beta)$ is -0.379 . The negative value of t-test and regression coefficient is indicates that this variable has the negative effect to dependent variable. Researcher can conclude that $\mathrm{H} 2$ is accepted (H0 is rejected) with the condition of DER has a negative but significant influence earning growth. It indicates that obtained from the rise and fall of DER ratio has affected of the amount of earnings growth. This research support the research conducted by Hartini (2012) that shows this variable has significance influence to earnings growth 
partially. DER gives high impact on improving earnings changes, meant to give effect to the company's profit. Kasmir (2009) said that DER higher the smaller of the financial leverage and the smaller the proportion of funds that lenders use to generate income.

\section{c. The Influence of Total Asset Turnover toward Earning Growth}

The result shows that the variable TAT has the t-result of 2.803 , with significance value (p-value) is 0.07 and is 0.300 . It has positive and significant influence on predicting earning growth (H3 is accepted). This indicates that the greater the ratio of TAT manufacturing companies then profit growth will increase. This research supported by the previous one that conducted by Hapsari (2007) that shows that TAT has positive and significance influence to earnings growth partially. This suggests that the better performance of the company, thus the investors are interested to invest their money, so it can increase its profit. This is consistent with the theory that states that the financial ratios TAT asset turnover indicates how fast a company that is used to generate profits. The greater the velocity of the assets owned by a company, the greater the profits earned by the company (Hartini, 2012).

\section{d. The Influence of Net Profit Margin toward Earning Growth}

The multiple regression analysis result shows that the t-test value of NPM is 4.757 with the significance of 0.000 and regression coefficient value $(\beta)$ is 0.504 . NPM has the positive value of the result and the significance value is less than $\alpha(0.05)$, it means the variable has the positive and significant influence on predicting earning growth .This supported by the journal of management that conducted by Setiawan (2012) that companies with a high ratio of NPM tend to have higher earnings growth as well, and vice versa. NPM high indicates that the company is able to increase its business through the achievement of operating profit in the period. The achievement of these earnings, investors will get a positive picture of the performance of the manufacturing company so that investors can expect a high return on its equity. Thus it can be said that earnings growth will also increase.

\section{e. The Influence of WCTA, DER, TAT and NPM toward Earning Growth in Simultaneously}

Based on the result of multiple regression statistical data, the coefficient of determinant $\left(\mathrm{R}^{2}\right)$ of earning growth is 0.372 . It means that $37.2 \%$ of predicting earning growth is explained by variability on independent variables taken that consists of WCTA, DER, TAT, and NPM. Then, the rest of $62.8 \%$ are explained by other variable that researcher not discuss in this study. The F-test result shows that the p-value (significance value) is 0.000 which lower than the $\alpha(0.05)$. This result is supported by the previous research conducted by Hartini (2012) that said there is a significant influence of variable financial ratio as independent variable to earnings growth as the dependent variable.

Hartini (2012) also said, financial ratios are often used to measure the strength or weakness faced by companies in the field of financial which basically is not only useful for internal corporate interests, but also for external parties. In addition, financial ratios can be used as an early warning system against the deterioration of the financial condition of a company, with financial ratios, investors can be guided to make a decision or a consideration of what would be achieved by the company and how the prospect to be faced in the future. The company is known prospects and is able to predict the dividend to be received in the future. Profit can give a positive signal about the future prospects of the company on the company's performance.

\section{Conclusions}

a) WCTA has a negative but significant influence on predicting earning growth partially with the significance value ( $\mathrm{p}$-value) is less than 0.05 but has the negative beta coefficient. WCTA will negatively affect the ability of earning growth, because most of the working capital is not spinning or experiencing unemployment in this condition. The company should decrease the WCTA to make the earning growing up.

b) DER has a negative but significant influence on predicting earning growth partially with the significance value ( $p$-value) is less than 0.05 but has the negative beta coefficient, with high DER in this condition that has the negative effect to earnings growth, companies bear the risk of loss is high in finding the opportunity to increase earnings growth.

c) TAT has a positive but significant influence on predicting earning growth partially with the significance value ( $p$-value) is less than 0.05 . The larger the company TAT shows efficient use of the entire assets of the company to generate net sales. The faster turnover of assets of a company to support the net sales, the revenue generated will increase and there is earning growth.

d) NPM has a positive but significant influence on predicting earning growth partially with the significance value ( $p$-value) is less than 0.05 . The greater of NPM indicates that the larger the net income derived from the company's sales activities. With the achievement of these earnings, investors will get a positive picture of the performance of the manufacturing company so that investors can expect a return of tall its capital. Thus it can be said that earnings growth will also increase.

e) Based on the results of the F test, proved that the significance $F$ value is 0.000 , which means less than a predetermined significance $(\alpha=0.05)$. So, the whole independent variables in this study simultaneously have significant effect on earnings 
growth as the dependent variable, with increasing growth in earnings from year to year, will give a positive signal about the company's performance.

\section{REFERENCES}

[1] Anderson, J. D. (2006). Qualitative and Quantitative research. Retrieved November 21, 2013, from Imperial COE: http://www.icoe.org/webfm_send/1936

[2] Ghozali, I. (2005). Aplikasi Analysis Multivariate dengan Program SPSS. Semarang: Badan Penerbit Universitas Diponegoro.

[3] Gitman, L. J. (2006). Principles of Managerial Finance (Eleventh ed.). New Jersey: Pearson Education, Inc.

[4] Gehring, N. (2013). Defining Financial Planning With the 4 Factor Decision Model. Retrieved November 8, 2013, from Journal of financial Planning: http://www.fpanet.org/journal/ DefiningFinancialPlanningWiththe4FactorModel/

[5] Gupta, S. (2012). Analysis of leverage ratio in selected Indian public sector and private sector banks. Asian Journal of Management Research, 3 (1), 12-19.

[6] Gujarati, D. (2004). Basic Econometrics (Fourth ed.). Ney York: McGraw Hill Inc.

[7] Hapsari, E. A. (2007). Analsis Rasio Keuangan Untuk Memprediksi Pertumbuhan Laba (Studi Kasus: Perusahaan Manufaktur yang terdaftar di Bursa Efek Jakartaperiode 2001-2005). Universitas Diponegoro, Semarang.

[8] Hartini, W. (2012). Pengaruh Financial Ratio Tehadap Pertumbuhan Laba Dengan Pengungkapan Cororate Social Responsibilitisebagai Variable Pemoderasi. Management Analysis Journal, 1 (2), 1-7.

[9] Herliana, Novriyadi, K., \&Wahyuni, T. (2012). Analisis Pengaruh Perputaran Persediaan Bahan Baku Terhadap Laba Perusahaan pada PT. Almi Caterindo Palembang. Thesis, Politeknik Pal Com Tech Palembang, Jurusan Akuntansi, Palembang.
[10] Hutami, R. P. (2012). Pengaruh Dividend Per Share, Return On Equity, dan Net Profit Margin terhadap Saham Perusahaan Industri Manufaktur yang Tercatat di BEI Periode 2006-2010. Jurnal Nominal, 1, 104-123.

[11] Indonesia-Investments. (2013, July 24). Indonesia's Mining Sector attracts most Investments despite Weak Export. Retrieved November 25, 2013, from Indonesia Investments: http://www.indonesia-investments.com/news/todays-headlin es/indonesias-mining-sector-attracts-most-investments-despi te-weak-export-market/item 938

[12] Kasmir. (2009). Analisis Laporan Keuangan. Jakarta: Rajawali Pers.

[13] Keown, A. J. (2005). Financial Management, Principles and Applications. (Tenth ed.). New Jersey: Pearson Education.

[14] Krishna G. Palepu, P. M. (2004). Business analysis \& valuation: using financial statements (Third ed.). Harvard: Thomson/South-Western College.

[15] Mohammed, N. K.-S. (2012). Using Altman's Model and Current Ratio to Assess the Financial Status of Companies Quoted In the Malaysian Stock Exchange. International Journal of Scientific and Research Publications, 2.

[16] Rietvield, P. S. (1994). 87 Masalah Pokok Dalamregresi Berganda. Yogyakarta: Andi Offset.

[17] Rudolf J. Freund, W. J. (2006). Regression Analysis (Second ed.). London: Elsevier Inc.

[18] Setiawan, D. E. (2010).Ekonometrika (1 ed.). (N. WK, Ed.) Yogyakarta: ANDI.

[19] Sugiyono. (2006). MetodePenelitianBisnis (9 ed.). Bandung: CV. Alvabeta.

[20] Suhardjono Bastian, I. (2006). AkuntansiPerbankan (First ed.). Jakarta: SalembaEmpat.

[21] Sunyoto, D. (2009). Analisis Regresidan UjiHipotesis. Yogyakarta: Media Presindo.

[22] Sutrisno. (2001). Manajemen Keuangan (First ed.). Yogyakarta: Ekonisia.

[23] Setiawan, Adi R. (2012). Analisis Pengaruh Kinerja Keuangandalam Memprediksi Pertumbuhan Laba. Jurnal Publikasi Manajemen, 10, 669-681. 